\title{
Developing Teaching Materials Based on Social Care Characters Based on Franciscan Spirituality With Contextual Teaching And Learning (CTL) Strategies
}

\author{
Elti L Gultom ${ }^{1}$, Aman Simaremare ${ }^{2}$, Rosmala Dewi ${ }^{2}$ \\ ${ }^{1}$ Master Student at State University of Medan (Unimed), Medan, Indonesia \\ ${ }^{2}$ Lecturer at State University of Medan (Unimed), Medan, Indonesia \\ ummiaisyahsiregar@gmail.com
}

\begin{abstract}
This study aimed to: (1) produce appropriate teaching materials to shape the social care character of early childhood, (2) produce effective teaching materials to shape the social care character of early childhood. This type of research was research and development $(R \& D)$ using the ADDIE development model. The quantitative data analysis technique used in this study was quantitative descriptive. Qualitative data obtained from the questionnaire were then converted to qualitative data on a scale of 5 (Likert scale). The findings showed that: (1) Teaching materials met the requirements and were appropriate to be used as teaching materials, based on the assessment of material experts, design experts, linguists, and practitioners/ teachers. The result of the validation of the material experts in all aspects of the material was $87.8 \%$ in the very good criteria, the result of the validation of the learning design expert in all the aspects was $90.4 \%$ in the very good criteria, and the validation of the linguists in all aspects was $93 \%$ in the very good criteria. The result of the teacher's response to teaching materials with a total average percentage of all aspects was $93.7 \%$ with the "very good" criteria. (2) The teaching material developed was more effective than without using the teaching material. The effectiveness of teaching materials based on social care character based on the values of Franciscan spirituality developed was $80.2 \%$, and based on Siswanto's theory was $81.36 \%$. The effectiveness before teaching materials was reviewed based on the values of Franciscan spirituality was $40.72 \%$, and based on Siswanto's theory was $41.2 \%$. Therefore, the development of pictorial story teaching materials was good enough to shape the social care character of early childhood.
\end{abstract}

Keywords: teaching materials; social care characters; franciscan spirituality values; ctl strategy.

\section{Introduction}

Individualist behavior, bullying, selfishness, forced will, and culture of etiquette (defiance) becomes a reflection of the fading of social care characters in early childhood due to the influence of technological development, this was evident from the observations and data collection at TK Santa Lusia. Based on the data obtained, Santa Lusia Kindergarten students were very interested in playing the internet in cyberspace with a minimum time of 2-4 hours/day and a maximum of 4-6 hours/day, the most desirable games were mobile legends, cooking games, and the most desirable films were Tayo, Upin-Ipin, Spongebob.

This game attracted the attention of children to continue to do it regardless of their social environment, ultimately it shaped the behavior of children becoming increasingly ignorant, when they were banned, then the children's reaction was anger, cry, fight, force the will, and rebel. The use of mobile phones, games, and film showed was very influential in the formation of children's character, children become individualistic, selfish, and manners became faded. The above problems were very serious. To avoid the disturbance of interaction/social interaction, selfish and negative effects of the use of mobile phones, television shows for early childhood, then the formation of social care character was important to be applied early on. 
Character education is implemented through modeling, habituation, and through the development of teaching materials. Teaching material is an important part of the learning process (Trianto, 2011). Teaching materials contain material content, learning media, learning resources, or a set of information that can be absorbed by students through fun learning. Teaching material in the context of this study was in the form of teaching pictorial stories. The pictorial stories teaching material was intended to help children better understand and be more interested in the material. Teaching material is related to or linked to real-world situations related to the formation of social care characters. This material was extracted from the values of Franciscan spirituality, namely prayer, repentance, humiliation and poverty/humility. Syukur (2005) states that Franciscan spirituality consists of four pillars of values namely prayer, continuous repentance, humiliation, and poverty/humility. The appreciation of this value will bring up the unique spirit of the Franciscans in the brotherhood, namely the spirit of joy, brotherhood, a peacemaker and justice.

The process of building characters needs to be exemplary and accustomed because it is the most probable element for making changes in life behavior in shaping the social care character of children (Purwanto, et al, 2017). Good and right example and habituation can instill the value of children's social care character.

In addition to the negative effects of technological progress, the process of shaping the social care character of early childhood is also influenced by how the learning process takes place in the classroom or at school in general. The tendency of teachers to teach is more focused on teaching science, while teaching materials about the formation of social care characters according to early childhood development is very minimal. This situation encouraged the researcher to provide solutions to develop teaching materials based on social care characters based on Franciscan spirituality with strategy Contextual Teaching and Learning. The availability of teaching materials based on social care characters based on Franciscan spirituality with Contextual Teaching and Learning strategies was expected to be a useful medium in shaping the social care character of early childhood.

\section{Literature Review}

\subsection{The character of Social Care}

Listyarti (in Tabi'in, 2017) states that the character of social care is an attitude and action that always wants to provide assistance to friends or the community in need. The problem of social care cannot be separated from social awareness. Social awareness is the ability to understand the meaning of social situations. Yusuf (in Mursid, 2017) states that some social behavioral skills are expected to appear in early childhood which is classified into aspects of the ability to build relationships with others, and then be developed into the curriculum in early childhood institutional units.

Wiyani (2015) states that to form the social care character, it is necessary to develop manners because manners are a procedure in social life or ways that are considered good in relationships among people. By knowing and implementing manners, a person will be well received by his environment and be respected as someone who knows and can apply manners.

\subsection{Values of Franciscan Spirituality}

Syukur (2005) states that Franciscan spirituality consists of four pillars of values, namely prayer, repentance, humiliation, poverty/humility. The appreciation of this value gives rise to 
the unique spirit of the Franciscans in the fraternity that is the spirit of prayer, joy, a peacemaker and justice. Syukur (2007) further states that spirituality is a special way or spirit of life in following Christ, with the same elements, namely brothers and sisters for all, love and forgive, care about social concerns, and peace. Syukur (2007) states that the elements of Franciscan spirituality are living in the love of God, brother to all and all creation, continuous repentance and peacemaker. The above opinion confirms that the form of concern in acting and behaving in the social environment of the Franciscan life is caring for others who suffer (option for the poor), caring for the universe and peacemakers in the midst of disputes.

The value of Franciscan spirituality is a description of various basic behaviors and attitudes that are expected to be owned by students as the basis for the formation of social care characters. The Franciscan spirituality values are more detailed contained in the following table:

\section{Table 1. Values of Franciscan Spirituality}

\begin{tabular}{|c|c|}
\hline $\begin{array}{c}\text { Values of Franciscan } \\
\text { Spirituality }\end{array}$ & Description \\
\hline $\begin{array}{l}\text { 1. Prayer, believe in God } \\
\text { Almighty and always } \\
\text { obey His teachings }\end{array}$ & $\begin{array}{l}\text { 1. Attitudes and behaviors that reflect beliefs in God } \\
\text { Almighty, the results of prayer are able to establish } \\
\text { good relationships with others and the universe }\end{array}$ \\
\hline 2. Continual repentance & $\begin{array}{l}\text { 1. Attitudes and behavior that humans are weak } \\
\text { creatures, ups, and downs in sin, then in } \\
\text { brotherhood we need constant repentance, to try to } \\
\text { change behavior towards better, both in words and } \\
\text { deeds. } \\
\text { 2. Doing prayer, fasting, alms (helping people who } \\
\text { need help). }\end{array}$ \\
\hline 3. Humiliation & $\begin{array}{l}\text { 1. Social attitude and care cultivate words of thanks, } \\
\text { excuse me, please, and apologize). } \\
\text { 2. Social attitudes and behaviors of children, namely } \\
\text { serving, proclaiming peace, not being arrogant, } \\
\text { brothers and sisters for all, not picking out friends, } \\
\text { not looking down on others }\end{array}$ \\
\hline 4. Poverty / humility & $\begin{array}{l}\text { 1. Attitudes and social behavior of children to be } \\
\text { brothers for all, build togetherness, a sense of } \\
\text { solidarity, and side with the small people (option } \\
\text { for the poor) } \\
\text { 2. Social attitudes and behavior of children, want to } \\
\text { share with friends, help friends who have } \\
\text { difficulties. Social sensitivity is sensitive to } \\
\text { situations and conditions. } \\
\text { 3. Not greedy, not stingy, and dare to say enough. } \\
\text { 4. Life-saving, honest in words and deeds. }\end{array}$ \\
\hline
\end{tabular}

Source: Franciscan Identity \& Franciscan Spirituality (Syukur, 2005) 


\subsection{Contextual Teaching and Learning (CTL) Learning Strategies}

Contextual approach (contextual teaching and learning) is a learning concept that helps teachers link between the material being taught and the students' real-world situation and encourage students to make connections between the knowledge they have and their application in their lives as family and community members. The learning process takes place naturally in the form of students working and experiencing, not transferring knowledge from teacher to student. Learning strategies are more important than results, (Riyanto, 2014).

Jhonson (in Komalasari, 2013) defines "Contextual Teaching and Learning enables students to connect the content of academic subjects with the immediate context of their daily lives to discover meaning".

Selvianiresa (2017) aruges that CTL learning can be successful, when learning used a collaborative interaction with students, a high level of activity in the lesson, a connection to real-world contexts, and an integration of science content with other content and skill areas. Syahputri (2019) conductes a research about applying CTL in reading comprehension on student and the result shows that CTL can improve students achievement in reading comprehension.

\subsection{Teaching Material Based on Social Care Character Based on Franciscan Spirituality with CTL Strategy}

The values of Franciscan spirituality, namely prayers, converts (brothers to all), humility (serving), poverty/humility were learning themes that would be developed in TK Santa Lusia that produce social care character-based teaching materials based on Franciscan spirituality with CTL strategies in shaping the social care character.

Developing teaching materials based on social care character based on Franciscan spirituality with CTL strategy in shaping social care character would have inspirational educative value by observing, studying teaching materials on Franciscan spirituality and the spiritual heritage of St. Francis to his followers who are trying to live the four pillars of values namely prayer, repentance (brother to all), humility (brother to the universe in its social environment), poverty / humility. Developing teaching materials can meet the needs of students by exploring the values of Franciscan spirituality in shaping social care characters in their social environment and can also improve the effectiveness of learning outcomes, especially in shaping social care characters, and that can be realized if teaching materials relevant to the basic competencies to be achieved are available, participation and activities of early childhood are more in the learning process.

\section{Methodology}

This type of research was research and development using the ADDIE development model. This research was conducted at TK Santa Lusia Sei Rotan, located on Medan St, Percut Sei Tuan District, Sei Rotan Village in Kindergarten B class, even semester 2018/2019 school year. Data collection techniques in the development of teaching materials were in the form of interviews and questionnaires. Developing teaching materials based on social care characters in the development of emotional-social intelligence was in the form of a questionnaire. There were three types of questionnaires arranged according to respondents from the study. The questionnaires were a questionnaire for material experts (lecturers), a questionnaire for learning design experts (lecturers), a questionnaire for linguists (lecturers), teacher assessment sheets 
and a child eligibility test questionnaire. Data analysis used a quantitative descriptive with a scale of 5 (Likert scale). Individual social care character values of early childhood could be calculated with the following conditions (Arikunto, 2009).

$$
\mathrm{N}=\frac{\text { Score Obtained }}{\text { Maximum score }} \mathrm{X} 100 \%
$$

Table 2. Categories of Early Childhood Social Care Characters

\begin{tabular}{|c|c|c|}
\hline No & Score & Category \\
\hline 1 & $81,00-100,00$ & Has become a habit \\
\hline 2 & $61,00,80,99$ & Already developed \\
\hline 3 & $41,00-60,99$ & Start to develop \\
\hline 4 & $21,00-40,99$ & Start to appear \\
\hline 5 & $0-20,99$ & Not appear yet \\
\hline
\end{tabular}

(Supinah \& Parmi, 2011)

Furthermore, the effectiveness of social care character-based teaching materials was obtained in the following way:

$$
\text { Effectiveness }=\frac{\text { total score obtained }}{\text { the ideal number of score }} \times 100 \%
$$

\section{Research Findings}

\subsection{Developing Teaching Materials Based on Social Care Character}

The step taken to produce good teaching materials was developing teaching materials with the ADDIE model. The following was a description of each stage carried out in developing these teaching materials.

a. Analysis Phase

At the defining stage, it was done by analyzing the curriculum, analyzing students' characteristics, analyzing the material, and formulating learning objectives.

b. Design Phase

The activities carried out in this phase were test preparation, media selection, format selection, and arranging the initial product of teaching materials.

c. Development Phase

This stage included: 1) validation of teaching materials by experts followed by revisions, 2) validation of teaching materials by practitioners followed by revisions, and 3) trials. The results of these stages were used as a basis for revision so that the developed teaching materials really meet the needs of users.

d. Implementation Phase

This implementation used teaching materials based on social care characters based on Franciscan spirituality with CTL strategies in learning activities; they studied individually and in groups. Individual learning was done when students do exercises or tasks that require independence, and groups heterogeneously consisting of 2-7 students doing characterbuilding activities through the teaching material being studied.

e. Evaluation Stage

The researcher conducted research for 5 consecutive weeks through teaching materials provided to determine changes in students' behavior after studying the pictorial story 
teaching material. Every weekend, the researcher assessed the results of the students' character development through the indicators and instruments that had been provided. On the fifth week at the last meeting, the results of the assessment of social care characters had changed to the stage where it had developed and the habituation stage. Students behaved and acted not because of being reminded or given a gift, but they had been already at the stage of awareness so that it was categorized as a social care character that had developed and at the habituation stage.

\subsection{Feasibility of Teaching Materials Based on Social Care Characters}

Teaching material based on social care characters based on Franciscan spirituality with a CTL strategy that was appropriate for shaping the social care character of young children had been done in several stages. This stage included: 1) validation of teaching materials by experts was followed by revisions; 2) validation of teaching materials by practitioners was followed by revisions, and 3) trials.

a. Expert Validation

- Content Feasibility

Material expert validation was by Dr. Godlif Sianipar, S.S., M.A., Ph.D. at stage I validation assessment based on aspects of content, components of curriculum assessment, users, material presentation, exercises, and content material. Learning aspects with three components were the opening component, core, and closing. The results of the material expert validation at the first and second meetings experienced a significant increase in the average percentage.

The average percentage of all aspects at the first meeting was $64.2 \%$, while at the second meeting; the average percentage of all aspects was $87.8 \%$. Therefore, the percentage results at the second meeting experienced a significant increase. This means that teaching materials developed were better in terms of material.

b. Feasibility of Presentation Design

The design expert validator was by Dr. Zulkifli, M.sn. Phase I validation was based on the content aspect which consisted of components of the learning approach, concept truth, concept depth, and concept suitability. Presentation aspects were four components, namely components of learning activities, activities, implementation, and assessment. Display aspects were six components, namely the component content, visualization, layout design/layout, image, teaching materials, and packaging. The validation results of the design experts at the first and second meetings experienced a significant increase in the average percentage.

The results of the average percentage of all aspects at the first meeting were 79\%, whereas, at the second meeting, the results of the average percentage of all aspects were $90.4 \%$. Therefore the percentage results at the second meeting increased significantly. This means that teaching materials developed were better in terms of design.

c. Language Feasibility

The linguist validator was Dr. Wisman Hadi, S.Pd., M.Hum. The results of the validation of linguists at the first and second meetings experienced a significant increase in the average percentage. 
The average percentage results for all aspects of linguists at the meeting I was $89 \%$, while at the second meeting, the average percentage of all aspects was $93 \%$. This was because all aspects of language teaching materials had been improved according to the revision of linguists. Therefore, the percentage results at the second meeting experienced a significant increase. This means that teaching materials developed were better in terms of language.

\section{d. Practitioner Analysis}

The average percentage of all aspects from practitioners/teachers at the first meeting was $85.7 \%$, while at the second meeting; the average percentage of all aspects was $93.7 \%$. This was because all aspects of the language of teaching materials had been improved according to the revision of the teacher. Therefore, the percentage results at the second meeting experienced a significant increase. This means that the teaching material developed was worth testing out in the field without further revision from the teachers.

\subsection{Trial of Teaching Material Based on Social Care Characters Based on Franciscan Spirituality Values with CTL Strategy}

The results of social care characters based on the values of Franciscan spirituality with the CTL strategy in the formation of the first week's character began to be seen obtaining a percentage of $80 \%$, began to develop and got a percentage of $20 \%$, the character of repentance was starting to get a percentage of $60 \%$, began to develop and got a percentage of $40 \%$, humiliation character was starting to get a percentage of $72 \%$, began to develop and got a percentage of $28 \%$, the character of poverty was starting to get a percentage of $72 \%$, began to develop and got a percentage of $28 \%$. The category of character formation was still in the stage of lacking qualifications so that the process of character building through teaching material needed to be studied and practiced repeatedly.

The results of social care characters based on the values of Franciscan spirituality with CTL strategy according to Siswanto's theory in the formation of the first week's character on obedience character began to be seen obtaining a percentage of $76 \%$, began to develop and got a percentage of $24 \%$, cooperating characters began to be seen obtaining a percentage of $64 \%$, began to develop and got a percentage of $36 \%$, honesty characters began to be seen obtaining a percentage of $72 \%$, began to develop and got a percentage of $28 \%$, manner characters began to be seen obtaining a percentage of $72 \%$, began to develop and got a percentage of $28 \%$. The category of character formation was still very poorly qualified so that the process of character building through teaching materials needed to be studied and practiced repeatedly.

Categories for the formation of children's social care characters in the first trial were still very poor qualifications. This was indicated by the weakness of teaching materials in trial I. The first week, children did not understand the meaning of images in teaching materials because the images were too dense, so that children experienced confusion. Likewise in learning activities, children had difficulty because in cutting and sticking puzzle activities provided with numbers were not suitable. Therefore, improvements were made first before the second week of testing.

The value of Franciscan spirituality with the CTL strategy in shaping the character of the second week on the character of the prayer began to be seen obtaining a percentage of $52 \%$, began to develop and got a percentage of $48 \%$, the character of repentance was starting to get a percentage of $48 \%$, began to develop and got a percentage of $52 \%$, humiliation character was starting to be seen getting a percentage of $20 \%$, began to develop and got a percentage of $80 \%$ 
the character of poverty began to be seen as getting a percentage of $72 \%$, began to develop and got a percentage of $28 \%$.

The results of social care characters based on the values of Franciscan spirituality with CTL strategy according to Siswanto's theory in the formation of the second week's character on the character of obedience began to be seen gaining a percentage of $56 \%$, began to develop and got a percentage of $44 \%$, cooperating character was starting to be seen getting a percentage of $36 \%$, began to develop and got a percentage of $64 \%$, honesty character was starting to be seen getting a percentage of $72 \%$, began to develop and got a percentage of $28 \%$, manner character was starting to be seen getting a percentage of $72 \%$, began to develop and got a percentage of $28 \%$.

The category of children's social care characters in trial II has increased compared to trial I, but still in very poor qualifications. This was indicated by the weakness of teaching materials in trial II. The second week, children did not understand the letters provided, especially the materials about let alone insert letters in words and form sentences, and children had difficulty because the language used in this teaching material was partly using English. Children had difficulty matching numbers with pictures because in one learning sheet there were 3 activities. Therefore, improvements were made before testing in the third week.

The results of social care character based on the values of Franciscan spirituality with CTL strategy in the formation of the third week's character on the character of the prayer began to be seen obtaining a percentage of $36 \%$, began to develop and got a percentage of $52 \%$, and had grown to obtain a percentage of $12 \%$ while the character of repentance began to be seen obtaining a percentage of $0 \%$, began to develop and got a percentage of $80 \%$, and had grown to get a percentage $20 \%$, while the character of humiliation began to be seen obtaining a percentage of $20 \%$, began to develop obtaining a percentage of $72 \%$, and had grown to get a percentage $8 \%$ while the character of poverty began to be seen getting a percentage of $12 \%$, began to develop obtaining a percentage of $60 \%$ and had grown to get a percentage of $28 \%$.

The results of social care characters based on the values of Franciscan spirituality with CTL strategy according to Siswanto's theory in the formation of the third week's character on obedience character began to be seen to obtain a percentage of $40 \%$, began to develop and obtained a percentage of $56 \%$, and had grown to get a percentage $4 \%$, while the cooperating character was starting to get a percentage of $44 \%$, began to develop and obtained a percentage of $56 \%$, honesty character was starting to get a percentage of $32 \%$, began to develop obtaining a percentage of $68 \%$, manner characters began to be seen to obtain percentage of $28 \%$, began to develop and got a percentage of $68 \%$ and had grown to get a percentage $4 \%$. The character building category was in the medium qualification stage, but the process of character building through teaching materials needs to be studied and practiced repeatedly. In the third week, children had begun to adjust to the activities of teaching materials and character formation practices carried out by children in accordance with the contents of the material.

The results of the social care character based on the values of Franciscan spirituality with CTL strategy in the formation of the fourth week's character on the character of the prayer began to develop obtaining a percentage of $12 \%$, had grown and got a percentage of $88 \%$, and began to be seen getting a percentage $0 \%$ while the character of repentance began to develop gaining a percentage of $20 \%$, had grown and got a percentage of $80 \%$, and began to be seen obtaining a percentage of $0 \%$, while humiliation character began to develop and obtained a percentage of $20 \%$, had already developed and obtained a percentage of $80 \%$, and began to develop and gained a percentage of $20 \%$ while poverty character had developed and gained a percentage of $80 \%$, had developed and obtained an of $20 \%$. The character building category 
was already in the stage of good qualifications but the process of character building through teaching materials still needed to be studied and practiced repeatedly.

According to Siswanto's theory in character formation, in the fourth week, the obedience character began to develop obtaining a percentage of $20 \%$, had grown and got a percentage of $80 \%$, while collaborating character began to develop and obtained a percentage of $20 \%$, had developed and gained a percentage of $80 \%$, honesty character began to develop and obtained a percentage of $20 \%$, already developed and gained a percentage of $80 \%$, manner character began to develop and obtained a percentage of $20 \%$, already developed and gained a percentage of $80 \%$. The category of character building was already in the qualification stage, but the process of character building through teaching materials needed to be studied and practiced repeatedly.

Based on the results of the study in the fourth week, children experienced changes in character; developed and higher category or in good qualifications, and the results of social care characters based on Siswanto's theory, that changes in character had developed in good qualifications. The fourth week, the students were accustomed to doing learning activities in accordance with the teaching material and they were happy with the pictures contained in the teaching material so that those could help the students to form social care characters until the category had become a habit. The effectiveness of teaching materials to get better qualifications were done in the fifth week.

The value of the social care character of individual students based on the values of Franciscan spirituality with the CTL strategy in the fifth week could be seen in the table:

Table 3. Results of Social Care Character Based on Franciscan Spiritual Values on Week V

\begin{tabular}{c|c|c|c|c|c|c|c|c|c}
\hline \multicolumn{10}{c|}{ The Fifth (V) Week Meeting } \\
\hline \multirow{2}{*}{ Score } & \multirow{3}{*}{ Category } & \multicolumn{2}{c|}{ Prayer } & \multicolumn{2}{c}{ Repentance } & Humiliation & Poverty \\
\cline { 3 - 11 } & & $\boldsymbol{f}$ & $\boldsymbol{\%}$ & $\boldsymbol{f}$ & $\boldsymbol{\%}$ & $\boldsymbol{f}$ & $\boldsymbol{\%}$ & $\boldsymbol{f}$ & $\boldsymbol{\%}$ \\
\cline { 3 - 11 } & & & & & & & & \\
\hline $81-100$ & BH & 7 & $28 \%$ & 7 & $28 \%$ & 7 & $28 \%$ & 7 & $28 \%$ \\
\hline $61-80$ & AD & 18 & $72 \%$ & 18 & $72 \%$ & 18 & $72 \%$ & 18 & $72 \%$ \\
\hline $41-60$ & SD & 0 & 0 & 0 & 0 & 0 & 0 & 0 & 0 \\
\hline $21-40$ & SA & 0 & 0 & 0 & 0 & 0 & 0 & 0 & 0 \\
\hline
\end{tabular}

Information:

$\mathrm{BH}=$ Has become a habit

$\mathrm{AD}=$ Already developed

$\mathrm{SD}=$ Start to develop

SA $=$ Start to appear

$\mathrm{AY}=$ Not appear yet

Based on the above table calculations, it was known that the results of social care characters based on the values of Franciscan spirituality with the CTL strategy in the formation of the fifth week's character on the character of the prayers had grown to obtain a percentage of $72 \%$, had become a habit by getting a percentage of $28 \%$, and the repentance character had grown to a percentage of $72 \%$, had become a habit by getting a percentage $28 \%$, humiliation character had grown to obtain a percentage of $72 \%$, had become a habit by getting a percentage $28 \%$, while the poverty character had grown to get a percentage of $72 \%$, had become a habit by getting a percentage $28 \%$. The category of character building was very good at qualification, 
but the process of character building through teaching materials needed to be learned and practiced repeatedly.

The results of students' social care character values based on Siswanto's theory with the CTL strategy in the fifth week could be seen in the table:

Table 4. Results of Building Social Care Characters Based on Siswanto's Theory on Week V The Fifth (V) Week Meeting

\begin{tabular}{c|c|c|c|c|c|c|c|c|c|}
\hline \multirow{2}{*}{ Score } & \multirow{2}{*}{ Category } & \multicolumn{2}{|c|}{ Obedience } & \multicolumn{2}{c|}{ Cooperation } & \multicolumn{2}{c|}{ Honesty } & \multicolumn{2}{c|}{ Manners } \\
\cline { 3 - 9 } & & $\boldsymbol{f}$ & $\boldsymbol{\%}$ & $\boldsymbol{f}$ & $\boldsymbol{\%}$ & $\boldsymbol{f}$ & $\boldsymbol{\%}$ & $f$ & $\boldsymbol{\%}$ \\
\cline { 3 - 10 } & & & & & & & & \\
\hline $81-100$ & BH & 7 & $28 \%$ & 7 & $28 \%$ & 7 & $28 \%$ & 7 & $28 \%$ \\
\hline $61-80$ & AD & 18 & $72 \%$ & 18 & $72 \%$ & 18 & $72 \%$ & 18 & $72 \%$ \\
\hline $41-60$ & SD & 0 & 0 & 0 & 0 & 0 & 0 & 0 & 0 \\
\hline $21-40$ & SA & 0 & 0 & 0 & 0 & 0 & 0 & 0 & 0 \\
\hline
\end{tabular}

Based on the above table calculations, it was known that the results of social care characters based on the values of Franciscan spirituality with CTL strategy according to Siswanto's theory in the formation of the fifth week's character on obedience character had grown to obtain a percentage of $72 \%$, had become a habit by getting a percentage of $28 \%$, the cooperating character had grown to get a percentage of $72 \%$, had become a habit by getting a percentage of $28 \%$, honesty character had grown to obtain a percentage of $72 \%$, had become a habit by getting a percentage of $28 \%$, manner character had grown to obtain a percentage of $72 \%$, had become a habit by getting a percentage of $28 \%$. The category of character building had a very good qualification stage but the process of character building through teaching materials needed to be studied and practiced repeatedly. The process of habituating characters into habits would produce good behavior. This was in line with Purwanto (2017: 209) stating that the process of shaping character requires exemplary and habituation because exemplary is the most absolute element to make changes in life behavior in preparing and shaping social care characters in early childhood.

\subsection{The effectiveness of teaching materials Based on Social Care Character}

Teaching materials based on social care characters based on the values of Franciscan spirituality with CTL strategies that had been developed were more effective than without using these teaching materials. The effectiveness of teaching materials based on social care characters based on the values of Franciscan spirituality developed was $80.2 \%$, and based on Siswanto's theory was $81.36 \%$. The effectiveness before teaching material was reviewed based on the values of Franciscan spirituality was $40.72 \%$, and based on Siswanto's theory was $41.2 \%$. The score was assessed through the results of an assessment of social care characters which were assessed individually in the form of pre-test and post-test, by seeing an increase in the assessment score before the social care character-based teaching materials were applied and after the social care character-based teaching materials were applied. 


\section{Conclusion}

Based on the discussion of the research findings of the process of developing teaching materials based on social care characters based on Franciscan spirituality with the CTL strategy described earlier, it could be concluded as follows:

5.1 The feasibility of developing teaching materials based on social care characters based on Franciscan spirituality with CTL strategies had met the requirements and suitable to be used as teaching materials, based on the assessment of material experts, design experts, linguists, and practitioners/teachers. The result of the validation of the material experts in all aspects of the material was $87.8 \%$ in the very good criteria, the result of the validation of the learning design expert in all the aspects was $90.4 \%$ in the very good criteria, and the validation of the linguists in all aspects was $93 \%$ in the very good criteria. The results of the teachers' response to teaching materials based on social care characters based on Franciscan spirituality with the CTL strategy developed had an overall average percentage of all aspects of $93.7 \%$ with the criteria of "very good". The trials in this study were continuously conducted until the results of the assessment of students' social care characteristics increased and in very good criteria. The trial was conducted once a week and lasted until the fifth week in this study.

5.2 The effectiveness of teaching materials based on social care characters based on Franciscan spirituality with the CTL strategy was declared effective. The results of the effectiveness of the use of teaching materials based on social care characters based on Franciscan spirituality with the CTL strategy were known in the final trial of teaching materials, namely in the fifth week. The results of the assessment in the fifth week served as posttest results. Teaching material based on social care characters based on the values of Franciscan spirituality with the CTL strategy developed was more effective than without using these teaching materials. The effectiveness of teaching materials based on social care characters based on the values of Franciscan spirituality developed was $80.2 \%$, and based on Siswanto's theory was $81.36 \%$. The effectiveness before teaching material reviewed based on the values of Franciscan spirituality was $40.72 \%$, and based on Siswanto's theory was $41.2 \%$. The score was seen through the results of the assessment of social care characters which were assessed individually in the form of pre-test and post-test, by seeing an increase in assessment scores before the implementation of social care character-based teaching materials and after the implementation of social care character-based teaching materials.

\section{References}

Arikunto, S. (2009). Dasar-Dasar Evaluasi Pendidikan. Jakarta: Bumi Aksara.

Komalasari, K. (2017). Pembelajaran Konstektual. Bandung: PT Refika Aditama.

Mursid. (2017). Pengembangan Pembelajaran PAUD. Bandung: PT Remaja Rosdakarya.

Riyanto, Y. H. (2014). Paradigma Baru Pembelajaran. Jakarta: Prenada Media Group.

Syukur, P. B. (2005). Identitas Fransisikan. Bogor: Percetakan Grafika Mardi Yuana.

Syukur, P. B. (2007). Spritualitas Fransiskan untuk Kaum Awam. Bogor: Percetakan Grafika Mardi Yuana.

Trianto. (2011). Desain Pengembangan Pembelajaran Tematik. Jakarta: Prenada Media Group. 
Tabi'in, A. (2017). Menumbuhkan Sikap Peduli Pada Anak Melalui Interaksi Kegiatan Sosial. Jurnal IJTIMAIYA, 39-59.

Purwanto, et al. (2017). Pengembangan Nilai-Nilai Karakter Anak Usia Dini Melalui Pembiasaan dan Keteladanan. Jurnal UNY, 203-213.

Wiyani, A. N. (2015). Bina Karakter Anak Usia Dini. Jakarta: Percetakan AR-RUZZ MEDIA. Syahputri, D., \& Mariyati, P. (2019). Improving Students' Achievement in Reading Comprehension by Applying Contextual Teaching and Learning (CTL). Budapest International Research and Critics in Linguistics and Education (BirLE-Journal), 5869.

Selvianiresa, D., \& Prabawanto, S. (2017). Contextual Teaching and Learning Approach of Mathematics in Primary Schools. (Journal of Physics: Conference Series), 1-7. 